\title{
Identification, characterization and potent antitumor activity of ECO-4601, a novel peripheral benzodiazepine receptor ligand
}

Henriette Gourdeau • James B. McAlpine - Maxime Ranger • Bryan Simard •

Francois Berger $\cdot$ Francis Beaudry $\cdot$ Chris M. Farnet $\cdot$ Pierre Falardeau

Published online: 22 October 2008

(C) Springer-Verlag 2008

Erratum to: Cancer Chemother Pharmacol (2008)

61:911-921

DOI 10.1007/s00280-007-0544-2

In this article the authors list has been revised to the following: Henriette Gourdeau, James B. McAlpine, Maxime Ranger, Bryan Simard, Francois Berger, Francis Beaudry, Chris M. Farnet and Pierre Falardeau.

The online version of the original article can be found under doi:10.1007/s00280-007-0544-2.

H. Gourdeau $(\bowtie) \cdot$ J. B. McAlpine $\cdot$ M. Ranger $\cdot$ C. M. Farnet

P. Falardeau

Thallion Pharmaceuticals Inc., 7150 Alexander-Fleming,

St Laurent, QC, Canada H4S 2C8

e-mail: hgourdeau@thallion.com

B. Simard · F. Berger

INSERM U318, Grenoble, France

F. Beaudry

Department of Veterinary Biomedicine,

Faculty of Veterinary Medicine, University of Montreal,

St Hyacinthe, QC, Canada J2S 2M2 